\title{
ДОСЛІДЖЕННЯ ГЕПАТОПРОТЕКТОРНОЇ АКТИВНОСТІ РІДКОГО ЕКСТРАКТУ ТРАВИ ЧАБЕРУ САДОВОГО ПРИ ТЕТРАХЛОРМЕТАНОВОМУ ГЕПАТИТІ
}

\author{
() М. І. Шанайда, О. М. Олещук, П. Г. Лихацький, І. 3. Кернична \\ ДВНЗ «Тернопільський державний медичний університет імені І. Я. Горбачевського \\ мОЗ України» \\ shanayda-mi@ukr.net
}

\begin{abstract}
Мета роботи. Вивчити гепатопротекторну активність рідкого екстракту трави чаберу садового (Satureja hortensis L.) при експериментальному гострому тетрахлорметановому гепатиті.

Матеріали і методи. Рідкий екстракт виготовлено шляхом послідовної екстракції подрібненої трави чаберу садового спиртом етиловим (70 \%, 50 \% та 30 \%) 3 наступним об'єднанням витягів та їх концентруванням; його дозування здійснювали в перерахунку на сухий залишок. Для моделювання гепатиту щурам дворазового вводили 50 \% олійний розчин тетрахлорметану у дозі 1 мл/кг маси тіла тварин. Для вивчення гепатопротекторної дії рідкого екстракту трави чаберу садового були вибрані дози 50 мг/кг, 100 мг/кг і 200 мг/кг маси тіла тварин; як препарат порівняння використовували «Силібор» у дозі 50 мг/кг.

Результати й обговорення. Введення піддослідним тваринам рідкого екстракту трави чаберу садового 3 профрілактичною метою на тлі тетрахлорметанового отруєння значно зменшило загальні прояви ураження. У ході експерименту вижили всі щури, які отримували екстракт, що вказує на перспективність вивчення його гепатопротекторноїдії. Найбільшвірогіднізміниудосліджуванихбіохімічнихпоказникахорганізмущурів встановлено при використанні екстракту у дозі 200 мг/кг: за впливом на вміст малонового діальдегіду, молекул середньої маси та коефріцієнт маси печінки досліджуваний екстракт достовірно не відрізнявся від ресреренс-препарату «Силібор», а за такими біохімічними показниками, як вміст загального білка і активністю супероксиддисмутази достовірно його перевершував. Використання доз екстракту 50 мг/кг і 100 мг/кг проявляло достовірний позитивний есрект тільки на деякі досліджувані показники уражених тварин.

Висновки. Профрілактичне введення рідкого екстракту трави чаберу садового у дозі 200 мг/кг ураженим тетрахлорметаном щурам суттєво знижувало інтенсивніть ураження печінки порівняно з контрольною патологією.

Ключові слова: тетрахлорметановий гепатит; рідкий екстракт; Satureja hortensis.
\end{abstract}

Вступ. Печінка є одним з ключових органів, які беруть участь в обміні речовин, оскільки забезпечує біотрансорормацію, детоксикацію та екскрецію різноманітних ксенобіотиків та ліків [4, 11]. Нераціональне харчування, шкідливі звички, низька фрізична активність, стреси та погіршення екологічної ситуації сприяють розвитку захворювань печінки та інших органів шлунково-кишкового тракту, що зумовлює необхідність пошуку ефективних та безпечних лікарських засобів 3 гепатопротекторним впливом [10, 19]. На фармацевтичному ринку України асортимент гепатопротекторів представлений переважно дорогими закордонними препаратами, які мають різноманітну хімічну природу та механізм дії. У лікуванні та профрілактиці захворювань печінки важливу роль відіграють засоби рослинного походження, які $є$ недорогими та забезпечують ефективне відновлення функціонування гепатоцитів [2, 13, 18, 19]. У зв'язку з цим пошук нових фрітопрепаратів для профрілактики та лікування гепатобіліарних розладів $€$ актуальним завданням сучасної фрармацевтичної науки і практики.
Чабер садовий (Satureja hortensis L.) є неофріцинальною лікарською рослиною родини Lamiaceae, яка за хімічним складом наближається до видів роду Thymus L. [7, 8]. Народна медицина рекомендує використовувати надземну частину рослини при деяких захворюваннях шлунково-кишкового тракту, артеріальній гіпертензії, бронхіті тощо $[8,23]$. Попередніми фрітохімічними дослідженнями надземної частини рослини встановлено, що у ній накопичується високий вміст таких сполук вторинного синтезу, як гідроксикоричні кислоти, фрлавоноїди та ефрірні олії [14, 22], які мають антиоксидантні, мембраностабілізуючі, протизапальні властивості [1, 18, 20].

Мета роботи - визначення можливої гепатопротекторної активності різних доз рідкого екстракту трави чаберу садового (РЕТЧ) порівняно з референс-препаратом «Силібор» при експериментальному гострому тетрахлорметановому гепатиті.

Матеріали і методи. Для отримання РЕТЧ здійснювали послідовну екстракцію подрібненої трави рослини спиртом етиловим (70 \%, 50 \% та $30 \%)$ з наступним

ISSN 2312-0967. Pharmaceutical review. 2017. № 2 
об'єднанням витягів та їх концентруванням [5]. Траву чаберу садового збирали у 2015 р. під час цвітіння в умовах культури на території Тернопільської обл. та сушили при температурі 30-35 C. Дозування РЕТЧ здійснювали в перерахунку на його сухий залишок.

Вибір модельної патології у щурів - гострого індукованого $\mathrm{CCl}_{4}$ гепатиту - зумовлений тим, що цей токсикант викликає морорологічні і біохімічні зміни печінки тварин, які близькі до проявів гострого токсичного гепатиту в людини [4]. Відповідно до даних Ю. І. Губського [4], при цій моделі гострого токсичного гепатиту ключова роль належить активації процесів перекисного окислення ліпідів (ПОЛ) у мембранах гепатоцитів.

Експериментальні дослідження проводили на базі центральної науково-дослідної лабораторії дВНЗ «Тернопільський державний медичний університет імені І. Я. Горбачевського МОЗ України» згідно [6] із дотриманням етичних принципів «Європейської конвенції про захист хребетних тварин, які використовуються для експериментальних та інших наукових цілей» [17]. Дослідження проводили на 72 білих безпородних статевозрілих щурах-самцях масою 180200 г, яких утримували на стандартному раціоні віварію; доступ до води був вільним.

Для вивчення гепатопротекторної дії РЕТЧ відповідно до [2, 6, 16] було обрано такі дози: 1/100, 1/50 і 1/25 від максимально введеної дози при визначенні гострої токсичності (5000 мг/кг), що становило 50 мг/кг, 100 мг/кг і 200 мг/кг маси тіла тварин. Як препарат порівняння використовували «Силібор» (виробник - фрармацевтична компанія “Здоров'я”, Україна), який вводили у дозі 50 мг/кг $[6,12]$. Таблетки «Силібор» після очищення від оболонок подрібнювали в ступці та вводили інтрагастрально у вигляді 1 \% крохмальної суспензії. Тваринам контрольної групи вводили воду дистильовану.

Експериментальних тварин поділили на 12 груп, по 6 у кожній групі. Біохімічні дослідження крові та печінки здійснювали на 4 та 7 доби експерименту, оскільки за даними літератури $[4,6,12]$ ці терміни відповідають періоду розпалу та початку ремісії гострого тетрахлорметанового гепатиту. Піддослідним тваринам (крім контрольної групи) моделювали патологію шляхом внутрішньоочеревинного дворазового через день введення $50 \%$ олійного розчину тетрахлорметану на оливковій олії у дозі 1 мл/кг маси тіла [16]. Різні дози РЕТЧ та «Силібор» тварини отримували за 60 хв до введення токсиканту (для виявлення профрілактичного есректу згідно 3 [6]) та впродовж наступних днів один раз на добу внутрішньошлунково крізь зонд; тваринам з групи контролю та контрольної патології раз на добу вводили аналогічний об'єм води дистильованої.

Тварини поділили на групи наступним чином: 1 група - контроль (вода дистильована), 2 група контрольна патологія, змодельований $\mathrm{CCl}_{4}$ гепатит +вода дистильована, 3 група - $\mathrm{CCl}_{4}$ гепатит + РЕТЧ у дозі 50 мг/кг, 4 група $-\mathrm{CCl}_{4}$ гепатит + РЕТЧ у дозі 100 мг/кг, 5 група - CCl $_{4}$ гепатит + РЕТЧ у дозі 200 мг/кг,
6 група - $\mathrm{CCl}_{4}$ гепатит + «Силібор» у дозі 50 мг/кг. Щури 1-6 груп раз на день через зонд отримували відповідний об'єм води дистильованої чи коригуючий чинник у певній дозі; тварин виводили з експерименту на 4 добу. 7 група - контроль (вода дистильована), 8 група - контрольна патологія, (змодельований $\mathrm{CCl}_{4}$ гепатит + вода дистильована), 9 група - $\mathrm{CCl}_{4}$ гепатит + РЕТЧ у дозі 50 мг/кг, 10 група $-\mathrm{CCl}_{4}$ гепатит + РЕТЧ у дозі 100 мг/кг, 11 група $-\mathrm{CCl}_{4}$ гепатит+ РЕТЧ у дозі 200 мг/кг, 12 група - $\mathrm{CCl}_{4}$ гепатит + «Силібор» у дозі 50 мг/кг. Щури 7-12 груп раз на день через зонд отримували відповідний об'єм води дистильованої чи коригуючий чинник у певній дозі впродовж 6 діб; тварин виводили з експерименту на 7 добу. Виведення тварин 3 експерименту здійснювали із дотриманням правил біоетики, знеживлюючи їх шляхом декапітації під тіопенталовим наркозом, та здійснювали забір печінки і крові для досліджень.

Про активність процесів ліпопероксидації та стан антиоксидантної системи судили за вмістом у гомогенатах печінки малонового диальдегіду (МДА) та активністю каталази (КT) $[2,4,16]$. Про активність процесів цитолізу судили за активністю трансаміназ - аланінамінотрансфрерази (АлАТ), аспартатамінотрансорерази (АсАТ); у сироватці крові піддослідних тварин також визначали вміст загального білка (ЗБ), активність лужної фросфратази (ЛФ) та супероксиддисмутази (СОД); рівень ендотоксикозу оцінювали за вмістом молекул середньої маси (МСM): ланцюгових (МСМл) при $\lambda=256$ нм і ароматичних (МСМа) при $\lambda=280$ нм $[3,4,9,12]$.

Коефріцієнт маси печінки (КМП) досліджуваних тварин, збільшення якого свідчить про набряк органу та порушення його кровообігу [6], встановлювали за такою фрормулою:

$$
\text { КМП }=\frac{m_{\text {печінки }}}{\mathrm{M}_{\text {тварини }}} \cdot 100 \%
$$

У ході експерименту оцінювали летальність тварин. Висновки про фрармакотерапевтичну ефрективність досліджуваного екстракту робили на основі біохімічних показників сироватки крові і гомогенату печінки, а також КМП.

Статистичну обробку даних виконували з використанням стандартного пакету статистичної програми «Statistica 10.0». У ході статистичного аналізу визначили середньоквадратичні відхилення, дисперсію та інші статистичні параметри; статистичну значущість встановлювали за $t$-критерієм Стьюдента. Для оцінки статистичної значущості відмінностей летальності тварин використовували кутове перетворення Фішера.

Результати й обговорення. Експериментальне ураження печінки тетрахлорметаном супроводжується летальністю піддослідних тварин. Встановлено, що у групі 2 (контрольна патологія 4 доба) на 2 добу експерименту загинула 1 тварина і у 8 групі (контрольна патологія 7 доба) на 5 добу експерименту загинула 1 тварина. Таким чином, летальність уражених нелікованих тварин склала 16,67 \% у групі відпо-

ISSN 2312-0967. Фармацевтичний часопис. 2017. № 2 
Фармакологічні дослідження біологічно активних речовин Pharmacological researches of biologically active substances

відно. В інших експериментальних групах вижили всі щури, що вказує на перспективність вивчення гепатозахисної дії досліджуваної фрітосубстанції $[4,6]$.
Результати біохімічних досліджень крові та печінки піддослідних тварин представлено в таблицях 1, 2. Оскільки інтоксикація тетрахлорметаном належить до

Таблиця 1. Показники гепатопротекторної активності РЕТЧ в умовах тетрахлорметанового ураження печінки, 4-та доба $(\mathrm{M} \pm \mathrm{m} ; \mathrm{n}=6(5))$

\begin{tabular}{|c|c|c|c|c|c|c|}
\hline \multirow[b]{2}{*}{ Показник } & \multicolumn{6}{|c|}{ Групи тварин } \\
\hline & контроль & $\begin{array}{c}\text { контрольна } \\
\text { патологія } \\
\left(\mathrm{CCl}_{4}\right)\end{array}$ & $\begin{array}{c}\mathrm{CCl}_{4+} \mathrm{PETU} \\
50 \mathrm{Mr} / \mathrm{K} \Gamma\end{array}$ & $\begin{array}{c}\mathrm{CCl}_{4+} \text { PETЧ } \\
100 \text { мг/кг }\end{array}$ & $\begin{array}{c}\mathrm{CCl}_{4+} \mathrm{PETU} \\
200 \mathrm{Mr} / \mathrm{Kr}\end{array}$ & $\begin{array}{c}\mathrm{CCl}_{4+} \\
\text { «Илібор» } \\
50 \text { мг/кг }\end{array}$ \\
\hline Номер групи & 1 & 2 & 3 & 4 & 5 & 6 \\
\hline КМП, \% & $3,37 \pm 0,03$ & $4,39 \pm 0,07^{1}$ & $4,25 \pm 0,09$ & $3,96 \pm 0,03^{2}$ & $3,63 \pm 0,02^{2}$ & $3,56 \pm 0,02^{2}$ \\
\hline \multicolumn{7}{|c|}{ Гомогенат печінки } \\
\hline КТ, мкат/кг & $6,31 \pm 0,02$ & $5,29 \pm 0,08^{1}$ & $5,41 \pm 0,05$ & $5,59 \pm 0,05^{2}$ & $5,88 \pm 0,04^{2}$ & $6,19 \pm 0,05^{2}$ \\
\hline МДА, мкмоль/л & $42,56 \pm 1,22$ & $66,24 \pm 0,84^{1}$ & $57,96 \pm 2,03^{2}$ & $52,32 \pm 1,39^{2}$ & $43,92 \pm 1,68^{2}$ & $46,6 \pm 1,36^{2}$ \\
\hline \multicolumn{7}{|c|}{ Сироватка крові } \\
\hline АлАТ, мкмоль/кг год & $0,41 \pm 0,01$ & $1,50 \pm 0,09^{1}$ & $0,94 \pm 0,05^{2}$ & $0,77 \pm 0,01^{2}$ & $0,56 \pm 0,02^{2}$ & $0,47 \pm 0,03^{2}$ \\
\hline АсАТ, мкмоль/кг год & $1,44 \pm 0,04$ & $2,21 \pm 0,11^{1}$ & $1,99 \pm 0,07$ & $1,94 \pm 0,02^{2}$ & $1,68 \pm 0,06^{2}$ & $1,42 \pm 0,04^{2}$ \\
\hline ЛФ, мккат/л & $3,31 \pm 0,04$ & $5,98 \pm 0,07^{1}$ & $4,38 \pm 0,12^{2}$ & $4,10 \pm 0,06^{2}$ & $3,88 \pm 0,08^{2}$ & $3,49 \pm 0,05^{2}$ \\
\hline Загальний білок, г/л & $70,16 \pm 1,39$ & $46,58 \pm 2,34^{1}$ & $52,50 \pm 0,61^{2}$ & $57,86 \pm 1,66^{2}$ & $68,46 \pm 1,24^{2}$ & $60,78 \pm 1,56^{2}$ \\
\hline СОД (мкмоль/л) & $4,75 \pm 0,09$ & $3,82 \pm 0,13^{1}$ & $4,120,09$ & $4,28 \pm 0,11^{2}$ & $4,48 \pm 0,05^{2}$ & $4,02 \pm 0,08^{2}$ \\
\hline МСМл, ум.од/л & $0,27 \pm 0,01$ & $0,43 \pm 0,04^{1}$ & $0,34 \pm 0,03$ & $0,32 \pm 0,05$ & $0,29 \pm 0,03^{2}$ & $0,28 \pm 0,02^{2}$ \\
\hline МСМа, ум.од/л & $0,09 \pm 0,01$ & $0,17 \pm 0,02^{1}$ & $0,14 \pm 0,01$ & $0,13 \pm 0,01$ & $0,12 \pm 0,01^{2}$ & $0,11 \pm 0,01^{2}$ \\
\hline
\end{tabular}

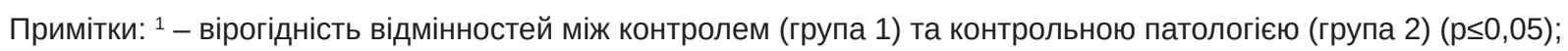

2 - вірогідність відмінностей між контрольною патологією (група 2) та лікованими тваринами (групи 3-6 відповідно) $(p \leq 0,05)$.

Таблиця 2. Показники гепатопротекторної активності РЕТЧ в умовах тетрахлорметанового ураження печінки, 7-ма

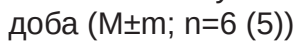

\begin{tabular}{|c|c|c|c|c|c|c|}
\hline \multirow[b]{2}{*}{ Показник } & \multicolumn{6}{|c|}{ Групи тварин } \\
\hline & контроль & $\begin{array}{c}\text { контрольна } \\
\text { патологія } \\
\left(\mathrm{CCl}_{4}\right)\end{array}$ & $\begin{array}{c}\mathrm{CCl}_{4+} \mathrm{PETЧ} \\
50 \mathrm{Mг} / \mathrm{K} \Gamma\end{array}$ & $\begin{array}{c}\mathrm{CCl}_{4+}+\mathrm{PETU} \\
100 \mathrm{Mr} / \mathrm{K \Gamma}\end{array}$ & $\begin{array}{c}\mathrm{CCl}_{4+}+\mathrm{PETU} \\
200 \mathrm{Mг} / \mathrm{K} \Gamma\end{array}$ & $\begin{array}{c}\mathrm{CCl}_{4+} \\
\text { «Силібор» } \\
50 \text { мг/кг }\end{array}$ \\
\hline Номер групи & 7 & 8 & 9 & 10 & 11 & 12 \\
\hline КМП, \% & $3,34 \pm 0,03$ & $4,32 \pm 0,05^{1}$ & $4,27 \pm 0,04$ & $4,10 \pm 0,07^{2}$ & $3,59 \pm 0,03^{2}$ & $3,54 \pm 0,08^{2}$ \\
\hline \multicolumn{7}{|c|}{ Гомогенат печінки } \\
\hline КТ, мкат/кг & $6,32 \pm 0,04$ & $5,37 \pm 0,03^{1}$ & $5,55 \pm 0,08$ & $5,72 \pm 0,06^{2}$ & $6,01 \pm 0,06^{2}$ & $6,29 \pm 0,07^{2}$ \\
\hline МДА, мкмоль/л & $42,64 \pm 1,03$ & $61,98 \pm 1,82^{1}$ & $55,51 \pm 1,35^{2}$ & $50,34 \pm 1,77^{2}$ & $44,03 \pm 1,11^{2}$ & $45,44 \pm 1,20^{2}$ \\
\hline \multicolumn{7}{|c|}{ Сироватка крові } \\
\hline АлАТ, мкмоль/кггод & $0,42 \pm 0,01$ & $1,41 \pm 0,01^{1}$ & $0,68 \pm 0,01^{2}$ & $0,60 \pm 0,02^{2}$ & $0,51 \pm 0,03^{2}$ & $0,43 \pm 0,04^{2}$ \\
\hline АсАТ, мкмоль/кггод & $1,47 \pm 0,02$ & $2,16 \pm 0,06^{1}$ & $1,96 \pm 0,05^{2}$ & $1,87 \pm 0,02^{2}$ & $1,65 \pm 0,07^{2}$ & $1,49 \pm 0,06^{2}$ \\
\hline ЛФ, мккат/л & $3,28 \pm 0,02$ & $5,84 \pm 0,09^{1}$ & $4,13 \pm 0,04^{2}$ & $3,95 \pm 0,06^{2}$ & $3,66 \pm 0,03^{2}$ & $3,17 \pm 0,07^{2}$ \\
\hline Загальний білок, г/л & $70,96 \pm 1,47$ & $50,76 \pm 3,56^{1}$ & $55,36 \pm 1,65^{2}$ & $63,08 \pm 1,71^{2}$ & $70,38 \pm 1,2^{2}$ & $62,31 \pm 1,46^{2}$ \\
\hline СОД (мкмоль/л) & $4,72 \pm 0,08$ & $3,61 \pm 0,14^{1}$ & $4,13 \pm 0,05^{2}$ & $4,31 \pm 0,07^{2}$ & $4,67 \pm 0,05^{2}$ & $4,22 \pm 0,06^{2}$ \\
\hline МСМл, ум.од/л & $0,27 \pm 0,01$ & $0,41 \pm 0,02^{1}$ & $0,33 \pm 0,03$ & $0,31 \pm 0,02^{2}$ & $0,27 \pm 0,03^{2}$ & $0,26 \pm 0,01^{2}$ \\
\hline МСМа, ум.од/л & $0,10 \pm 0,01$ & $0,17 \pm 0,02^{1}$ & $0,14 \pm 0,04$ & $0,12 \pm 0,01^{2}$ & $0,10 \pm 0,01^{2}$ & $0,11 \pm 0,02^{2}$ \\
\hline
\end{tabular}

Примітки: ${ }^{1}$ - вірогідність відмінностей між контролем (група 1) та контрольною патологією (група 2) $(p \leq 0,05)$;

2 - вірогідність відмінностей між контрольною патологією (група 2) та лікованими тваринами (групи 3-6 відповідно) $(p \leq 0,05)$.

ISSN 2312-0967. Pharmaceutical review. 2017. № 2 
Фармакологічні дослідження біологічно активних речовин Pharmacological researches of biologically active substances

передбачуваного дозозалежного типу уражень ксенобіотиками, ключовим механізм розвитку оксидативного стресу є підвищення вмісту активних фрорм кисню, які є продуктами клітинного метаболізму (вільні радикали, продукти неповного відновлення атомарного кисню, пероксид водню тощо) та спричиняють порушення структури та фрункції гепатоцитів $[4,11]$.

Доведено [4, 9], що в інактивації супероксидних аніонів значну роль відіграє СОД, активність якої в сироватці крові уражених тетрахлорметаном досліджуваних тварин знижується на 4-ту і 7-му доби на 19,6 \% і 23,5 \% відповідно (див. табл. 1, 2). Важливим показником активації пОЛ у результаті ушкодження клітин печінки є накопичення МДА - продукту перекисної деградації жирних кислот біомембран [4, 9]. Як видно 3 даних таблиці 1 та таблиці 2, після введення гепатотоксину рівень МДА у гомогенаті печінки уражених нелікованих тварин зростає на 55,7\% і 45,4 \%, відповідно, на 4-ту і 7-му добу; дещо менше змінюється рівень КТ (зменшується на 19,3 \% і 17,7 \% відповідно).

Активність ЛФ як показник холестазу найбільш сильно підвищувалась в сироватці крові уражених нелікованих тварин на 4-ту добу отруєння тетрахлорметаном (див. табл. 1, 2). Згідно 3 [4], токсичне ураження мембранних структур гепатоцитів хлоралканами, як правило, призводить до вираженої гіперферментемії за рахунок вивільнення індикаторних внутрішньоклітинних фрерментів. Активність трансаміназ як органоспециорічних фрерментів печінки є показником цитолізу гепатоцитів. Ми спостерігали значне їх зростання в сироватці крові уражених тварин в обидва періоди дослідження АлАТ - у 3,66 і 3,36 раза, АсАТ - у 1,53 і 1,47 раза (на 4-ту і 7-му доби відповідно).

Важливим маркером ендогенної інтоксикації організму при патологічних процесах є концентрація так званих «молекул середньої маси» (пептиди, продукти деградації білків, ліпідів та ін.), у яких молекулярна маса становить від 300 до 5000 Д [3]. У ході експерименту спостерігали збільшення цих показників в сироватці крові уражених тварин, особливо на 4-ту добу: на 59,3 \% МСМл і на 88,9 \% МСМа.

Таким чином, на основі аналізу отриманих результатів можна стверджувати, що введення $\mathrm{CCl}_{4}$ викликало в щурів однотипну патологічну реакцію, яка супроводжувалась характерними для гострого тетрахлорметанового гепатиту змінами, а саме зростанням активності трансаміназ та показників холестазу, активацією процесів ліпопероксидації та збільшенням маси печінки.

Введення досліджуваних фрітосубстанцій і референс-препарату попереджало загибель тварин, про що свідчить відсутність летальності в усіх експериментальних групах тварин, які отримували РЕТЧ та «Силібор».

У результаті введення піддослідним тваринам, ураженим $\mathrm{CCl}_{4}$, різних доз РЕТЧ і «Силібору» (див. табл. 1, 2), спостерігали тенденцію до покращання вищенаведених показників, що вказує на поступовий процес відновлення фрізіологічного стану печінки. Максимальне відновлення більшості біохімічних показників встановлено при застосуванні референспрепарату та РЕТЧ у дозі 200 мг/кг, тоді як дози 50 мг/кг і 100 мг/кг не завжди нормалізували стан тварин (див. табл. 1, 2).

Вірогідне зростання вмісту загального білка, яке опосередковано може свідчити про нормалізацію білоксинтетичної функції печінки, найбільш виражено спостерігалось в сироватці крові уражених тварин при застосуванні РЕТЧ в дозі 200 мг/кг (на 46,9 \% та 38,7 \%, відповідно, на 4-ту і 7-му добу); аналогічно спостерігали найбільш істотне зростання СОД при застосуванні цієї дози ектракту (на 17,3 \% та 29,4 \% відповідно). Рівні КМП, МДА, МСМл і МСМл при дії максимальної дози РЕТЧ достовірно не відрізнялась від есректу препарату порівняння.

Збільшення КМП уражених тварин порівняно з інтактними свідчить про наявність значної інтоксикації (див. табл. 1, 2). Встановлено, що після проведення корекціі ураження шляхом введення різних доз фрітосубстанції та «Силібору» досліджуваний показник значно покращився.

Згідно з літературними даними [11, 13, 17], застосування екстрактів з рослинної сировини сприяє нормалізацію стану антиоксидантної системи піддослідних тварин. Гепатопротекторна активність екстракту іншого виду чаберу - Satureja macrostema, яка була встановлена при дослідженні гострого та хронічного ураження щурів ксенобіотиками, виявляється в нормалізації процесів ПОЛ [21] та, згідно з обгрунтуванням авторів, зумовлена високим вмістом фенольних сполук в сировині рослини.

Нашими попередніми дослідженнями встановлено високий вміст фрлавоноїдів (апігенін, лютеолін та їх похідні; рутин, гіперозид) та гідрокискоричних кислот (розмаринова, ферулова та ін.) у водно-спиртових екстрактах трави Satureja hortensis [14, 15, 22], які відомі своїми антиоксидантними, мембраностабілізуючими та протизапальними властивостями [1, 18]. Однією 3 найважливіших фрункцій френольних сполук $є$ здатність до оборотного окиснення 3 утворенням хінонів, що забезпечує відновлювальний вплив на низку компонентів мембран та зменшення ексудативної фрази запального процесу [1].

Висновки. Результати проведених досліджень свідчать, що профрілактично-лікувальне введення щурам рідкого екстракту трави чаберу садового при тетрахлорметановому гепатиті суттєво знижувало інтенсивність ураження печінки порівняно 3 групою контрольної патології. Найбільш виразні зміни досліджуваних біохімічних показників щурів встановлено при використанні екстракту у дозі 200 мг/кг: за впливом на вміст малонового діальдегіду, молекул середньої маси та коефріцієнт маси печінки досліджуваний

ISSN 2312-0967. Фармацевтичний часопис. 2017. № 2 
Фармакологічні дослідження біологічно активних речовин Pharmacological researches of biologically active substances

екстракт достовірно не відрізнявся від ресреренспрепарату «Силібор», а за такими показниками, як вміст загального білка та активність супероксиддисмутази вірогідно перевершував його.

\title{
ИССЛЕДОВАНИЕ ГЕПАТОПРОТЕКТОРНОЙ АКТИВНОСТИ ЖИДКОГО ЭКСТРАКТА ТРАВЫ ЧАБЕРА САДОВОГО ПРИ ТЕТРАХЛОРМЕТАНОВОМ ГЕПАТИТЕ
}

\section{М. И. Шанайда, А. М. Олещук, П. Г. Лихацкий, И. 3. Керничная}

\author{
ГВУз «Тернопольский государственный медицинский университет имени И. Я. Горбачевского \\ МЗ Украины» \\ shanayda-mi@ukr.net
}

\begin{abstract}
Цель работы. Исследовать гепатопротекторную активность различных доз жидкого экстракта травы чабера садового (Satureja hortensis L.) при экспериментальном остром тетрахлорметановом гепатите.

Материалы и методы. Жидкий экстракт изготовлен путем последовательной экстракции измельченной травы чабера садового спиртом этиловым (70 \%, 50 \% и 30 \%) с последующим объединением извлечений и их концентрированием; его дозирование осуществляли в пересчете на сухой остаток. Для моделирования гепатита крысам двукратно вводили 50 \% масляный раствор тетрахлорметана в дозе 1 мл/кг массы тела животных. Для изучения гепатопротекторного действия различных доз жидкого экстракта травы чабера садового выбраны дозы 50 мг/кг, 100 мг/кг и 200 мг/кг массы тела животных; как препарат сравнения использовали «Силибор» в дозе 50 мг/кг.

Результаты и обсуждение. Введение подопытным животным жидкого экстракта травы чабера садового с профилактической целью на фоне тетрахлорметанового гепатита значительно уменьшило общие проявления интоксикации. Выжили все крысы, получавшие исследуемый экстракт, что указывает на перспективность изучения его гепатопротекторного действия. Наиболее выраженные изменения исследуемых биохимических показателей установлены при использовании экстракта в дозе 200 мг/кг: по влиянию на содержание малонового диальдегида, молекул средней массы и коэффрициент массы печени исследуемый экстракт в дозе 200 мг/кг достоверно не отличался от референс-препарата «Силибор», а по таким показателям, как содержание общего белка и активности супероксиддисмутазы достоверно его превышал. Использование доз 50 мг/кг и 100 мг/кг не всегда оказывало достоверный положительный эффект на исследуемые показатели состояния животных.

Выводы. Профилактическое введение исследуемого жидкого экстракта травы чабера садового в дозе 200 мг/кг крысам с моделью тетрахлорметанового гепатита существенно снижало интенсивность поражения печени по сравнению с контрольной патологией.
\end{abstract}

Ключевые слова: тетрахлорметановый гепатит; жидкий экстракт; Satureja hortensis.

\section{STUDY OF HEPATOPROTECTIVE ACTIVITY OF LIQUID EXTRACT OF SUMMER SAVORY HERB UNDER CONDITION OF TETRACHLOROMETHANE HEPATITIS}

\section{I. Shanaida, O. M. Oleshchuk, P. H. Lykhatskyi, I. Z. Kernychna}

\author{
I. Horbachevsky Ternopil State Medical University \\ shanayda-mi@ukr.net
}

The aim of the work. It was carried out the investigation of the hepatoprotective activity of liquid extract of Summer Savory (Satureja hortensis L.) herb on a model of acute liver injury caused by carbon tetrachloride.

Materials and Methods. The liquid extract was prepared by extracting the herb with ethanol (70 \%, $50 \%$ and $30 \%)$, followed by combining and concentrating these extracts; its dosage was carried out according to the dry residue. It was twice administered the $50 \%$ tetrachloromethane solution at a dose of $1 \mathrm{ml} / \mathrm{kg}$ of body weight of rats for induction of hepatitis. Doses of $50 \mathrm{mg} / \mathrm{kg}, 100 \mathrm{mg} / \mathrm{kg}$ and $200 \mathrm{mg} / \mathrm{kg}$ of the liquid extract were chosen for studying of their hepatoprotective activity; «Silibor» was used as a reference drug in a dose of $50 \mathrm{mg} / \mathrm{kg}$.

Results and Discussion. Using of the liquid extract of Summer Savory herb with preventive maintenance against the tetrachloromethane hepatitis in rats significantly reduced the general manifestations of intoxication. All rats after receiving the extract have survived, and it can indicate the prospect of hepatoprotective activity of investigated extract. The most significant changes of biochemical parameters set by using the extract at a dose of $200 \mathrm{mg} / \mathrm{kg}$. Investigated extract at dose $200 \mathrm{mg} / \mathrm{kg}$ did not significantly differ from the reference drug according to influence on the content of malonic dialdehyde, molecules of average weight and the coefficient of liver mass. It prevailed over the «Silibor» by such biochemical parameters

ISSN 2312-0967. Pharmaceutical review. 2017. № 2 
Фармакологічні дослідження біологічно активних речовин Pharmacological researches of biologically active substances

as the content of total protein and superoxide dismutase. Using of $50 \mathrm{mg} \mathrm{kg}$ and $100 \mathrm{mg} / \mathrm{kg}$ doses did not always have a normalizing effect on data of affected animals.

Conclusions. This study determined the hepatoprotective effect of Summer Savory liquid extract at the dose of $200 \mathrm{mg} / \mathrm{kg}$ after administration to tetrachloromethane-affected rats.

Key words: tetrachloromethane hepatitis; liquid extract; Satureja hortensis.

\section{Список літератури}

1. Барабой В. А. Растительные френолы и здоровье человека / В. А. Барабой. - М. : Наука, 1984. - 160 с.

2. Галузінська Л. В. Експериментальне вивчення гепатопротекторної активності полісренольного екстракту з надземної частини лядвенцю рогатого / Л. В. Галузінська // Укр. біофарм. журнал. - 2013. - № 1(24). - С. 28-33.

3. Громашевская Л. Л. «Средние молекул» как один из показателей метаболической интоксикации в организме / Л. Л. Громашевская // Лаб. диагностика. - 1997. -№ 1. - С. 11-16.

4. Губский Ю. И. Коррекция химического поражения печени / Ю. И. Губский. - К. : Здоров'я, 1989. - 168 с.

5. Державна Фармакопея України / Державне підприємство «Науково-експертний фрармакопейний центр». - 1-е вид. - Харків : РІРЕГ, 2001. - Доповнення 1. $-2004 .-$ С. $271-274$.

6. Доклінічні дослідження лікарських засобів (методичні рекомендації) / За ред член-кор. АМН України О. В. Стесранова. - Київ : Авіценна, 2001. - С. 334-352.

7. Зарівна Н. О. Стандартизація рідкого екстракту чебрецю повзучого / Н. О. Зарівна, Л. В. Вронська // Укр. біосрарм. журнал. - 2012. - № 5-6. - С. 108-112.

8. Лікарські рослини: енциклопедичний довідник / Відп. ред. А. М. Гродзинський. - К. : Вид-во «Українська енциклопедія» ім. М. П. Бажана, 1992. - С. 455.

9. Мартишук Т. В. Вплив оксидаційного стресу на систему антиоксидантного захисту організму щурів / Т. В. Мартишук // Вісник Дніпроп. ун-ту. Біологія, медицина. - 2016. - 7(1). - С. 8-12.

10. Олещук О. М. Дослідження гепатопротекторних властивостей мелатоніну та ролі поліморфізму гена MTNR1B у пацієнтів із цукровим діабетом 2 типу / О. М. Олещук, Я. І. Іванків, О. А. Шумська // Медична та клінічна хімія. - 2016.- Т. 18, № 4. - С. 50-54.

11. Пентюк А. А. Поражения печени ксенобиотиками / А. А. Пентюк, Л. В. Мороз, О. В. Паламарчук // Соврем. проблемы токсикологии. - 2001. - № 2. - С. 8-16.

12. Пида В. П. Застосування густого екстракту з обліпихи крушиновидної в умовах хронічного комбінованого гепатиту в щурів / В. П. Пида // Медична хімія. - 2011. T. 13, № 1. - C. 78-81.

13. Попович В. П. Гепатопротекторний потенціал рослин: монографрія / В. П. Попович, Б. П. Громовик,
В. А. Сятиня. - К. : Інтерсервіс, 2012. - 188 с.

14. Шанайда М. І. Вивчення якісного складу та кількісного вмісту фрлавоноїдів у траві представників підродини Nepetoideae родини Lamiaceae // M. І. Шанайда // Фарм. журнал. - 2015. - № 4. - С. 71-76.

15. Шанайда М. И. Качественный состав и количественное содержание гидроксикоричных кислот в надземной части культивируемых представителей семейства Lamiaceae / М. И. Шанайда, C. М. Марчишин // Вестник ЮКГФА. - 2016. - № 1 (74). - С. 23-26.

16. Штробля А. Л. Підбір мінімально діючої дози сухого екстракту 3 листя абрикоса звичайного на моделі тетрахлорметанового ураження печінки / А. Л. Штробля, Л. С. Фіра, П. Г. Лихацький // Фармацевтичний часопис. - 2012. - № 3. - C. 132-135.

17. European convention for the protection of vertebrate animals used for experimental and other scientific purposes. - Council of Europe: Strasbourg, 1986. - 53 p.

18. Foti M.C. Antioxidant properties of phenols / M. C. Foti // J. Pharm. Pharmacol. - 2007. - Vol. 59 (12). - P.16731685.

19. Tresina P. S. Hepatoprotective activity of Aristolochia bracteata Retz against carbon tetrachloride induced hepatic damage / P. S. Tresina, K. Paulpriya, V. R. Mohan // Int. J. Pharm. Sci. Rev. Res. - 2016. - Vol. 40 (1), No. 32. - P. 164-169.

20. Khomdram S. Polyphenolic compounds and free radical scavenging activity in eight Lamiaceae herbs of Manipur / S. Khomdram, K. Potsangbam // Not. Sci. Biol. - 2011. Vol. 3. - P. 108-113.

21. Perez Gutierrez R. M. Antioxidant and hepatoprotective effects of the methanol extract of the leaves of Satureja macrostema / R. M. Perez Gutierrez, Y. T. Gallardo Navarro // Pharmacogn. Mag. - 2010. - Vol. 6(22). - P. 125-131.

22. Shanaida M. Phytochemical analysis of secondary metabolites of Satureja hortensis L. / M. Shanaida, I. Ivanusa, I. Kernychna // Int. J. Pharm. Pharm. Sci. - 2017. Vol. 9 (2). - P. 315-318.

23. Summer Savory: from the selection of traditional applications to the novel effect in relief, prevention, and treatment of a number of serious illnesses / R. Hamidpour, S. Hamidpour, M. Hamidpouret [et al.] // J. Tradit. Compl. Med. 2014. - Vol. 4(3). - P. 140-144.

tive activity of the polyphenolic extract of aerial parts lyadventsyu horned]. Ukr. biofarm. zhurnal. 2013;1(24): 28-33. Ukrainian.

3. Gromashevskaya LL. ["Average molecules" as one of

\section{References}

1. Baraboy VA. Plant phenols and human health. [Растительные френолы и здоровье человека] Moscow: Nauka; 1984. Russian.

2. Galuzinska LV. [Experimental study of hepatoprotec-

ISSN 2312-0967. Фармацевтичний часопис. 2017. № 2 
Фармакологічні дослідження біологічно активних речовин

Pharmacological researches of biologically active substances

the factor of body metabolic intoxication]. Lab. diagnostika. 1997;1: 11-6. Russian.

4. Gubskiy Yul. Correction of liver chemical demage. [Корекция химического поражения печени]. K.: Zdorovya, 1989. Russian.

5. [Derzhavna Farmakopeia Ukrainy] / Derzhavne pidpryiemstvo «Naukovo-ekspertnyi farmakopeinyi tsentr». 1-e vyd. Dopovnennia 1. Kharkiv: RIREG; 2004. Ukrainian. 6. [Doklinichni doslidzhennia likarskykh zasobiv (metodychni rekomendatsii)] Za red. chlen-kor. AMN Ukrainy OV. Stefanova. Kyiv: Avicenna; 2001. Ukrainian.

7. Zarivna NO, Vronska LV. [Standartization of liquid extract of savory herb]. Ukr. biofarm. zhurnal. 2012;5-6:108-12. Ukrainian.

8. Medicinal herbs : encyclopedic guide. [Лікарські рослини: енциклопедичний словник] Vidp. red. A.M. Hrodzynskyi. K.: Vyd-vo "Ukrainska entsyklopediia" im. M.P. Bazhana; 1992. Ukrainian.

9. Martyshuk TV. [Influence of oxydative stress on the system of antioxidant defence of rats' body]. Visnyk Dniprop. un-tu. Biolohiia, medytsyna. 2016;7(1): 8-12. Ukrainian.

10. Oleshchuk OM, Ivankiv Yal, Shumska OA. [Study of hepatoprotective melatonin properties and the role of polymorphism of MTNR1B gene in patients with diabetes mellitus type 2]. Medychna ta klinichna khimiia. 2016;18 (4): 50-4. Ukrainian.

11. Pentyuk AA, Moroz LV, Palamarchuk OV. [Liver lesion by xenobiotics]. Sovremennye problemy toksikologii. 2001;2: 8-16. Russian.

12. Pyda VP. [Use of dense extract of buckthorn in the condition of chronic combined hepatitis in rats]. Medychna khimiia. 2011;13(1): 78-81. Ukrainian.

13. Popovych VP, Hromovyk BP, Siatynia VA. Hepatoprotective potential of herbs : monography. [Гепатопротекторний потенціал рослин : монографрія] К.: Interservis; 2012. Ukrainian.
14. Shanaida MI [Study of qualitative composition and quantitative content of flavanoids in the herb of representatives of Nepetoideae Lamiaceae]. Farm. zhurnal. 2015;4: 71-6. Ukrainian.

15. Shanayda MI, Marchyshyn SM. [Qualitative composition and quantitative content of hydroxycoric acids in aboveground part of cultivated representatives of Lamiaceae family]. Vestnik YUKGFA. 2016;1(74): 23-6. Russian. 16. Shtroblya AL, Fira LS, Lykhaky PG [Selection of minimally active dose of dry extract from leaves of apricot on conventional models of liver injury by tetrachlormethane]. Farmatsevtychnyi chasopys. 2012;3: 132-5. Ukrainian.

17. [European convention for the protection of vertebrate animals used for experimental and other scientific purposes]. Council of Europe: Strasbourg; 1986.

18. Foti MC. [Antioxidant properties of phenols] J Pharm Pharmacol. 2007; 59(12): 1673-85.

19. Tresina PS, Paulpriya K, Mohan VR [Hepatoprotective activity of Aristolochia bracteata Retz against carbon tetrachloride induced hepatic damage] Int J Pharm Sci Rev Res. 2016;40(1), No. 32: 164-9.

20. Khomdram S, Potsangbam K. [Polyphenolic compounds and free radical scavenging activity in eight Lamiaceae herbs of Manipur] Not Sci Biol. 2011;I.3: 108-13.

21. Perez Gutierrez RM, Gallardo Navarro YT [Antioxidant and hepatoprotective effects of the methanol extract of the leaves of Satureja macrostema] Pharmacogn Mag. 2010;6(22): 125-31.

22. Shanaida M, Ivanusa I, Kernychna I. [Phytochemical analysis of secondary metabolites of Satureja hortensis L.] Int J Pharm Pharm Sci. 2017;9(2): 315-8.

23. Hamidpour R, Hamidpour S, Hamidpour M, Shahlari M, Sohraby M. [Summer Savory: from the selection of traditional applications to the novel effect in relief, prevention, and treatment of a number of serious illnesses] $\mathrm{J}$ Tradit Compl Med. 2014;4(3): 140-4. 